\title{
Analysis on Chinese OFDI Investment Structure of EU
}

\author{
Xin-ying LIU ${ }^{1, a}$ and Xue-yao FENG ${ }^{2, b}$ \\ ${ }^{1}$ Teaching in Shandong University of Finance and Economics, \\ Shandong Province, China \\ ${ }^{2}$ Studying in Shandong University of Finance and Economics, \\ Shandong Province, China \\ ae-mail:sheila_guo1998@hotmail.com, be-mail:fengxy1993@126.com
}

Keywords: Chinese ofdi to EU, Investment geographical structure, Investment industrial investment.

\begin{abstract}
EU, one of the most important economics in the world, whose total GDP has surpassed the USA, which laid its vital place. And China is the top company among its trade partner. Since the Chinese government putted forward the opening strategy in 2000, the overall trend of Chinese ofdi to Europe has increased all the time despite it fell 15.4\% in 2013.Aan the trend showed a "jump" of growth especially based the environment of European debt crisis. The article mainly analyzed its geographical and industrial structure. What's more, it analyzed the further characterize of its distribution, then draws some conclusions. As a result, it drew some strategies for Chinese development.
\end{abstract}

\section{Introduction}

With the rapid development of China' economy, Chinese FDI has reached $\$ 87.8$ billion which ranked third in the world and lowered to the US only in 2012. It exceeded 100 billion marks and rose to $\$ 107.84$ billion which won the world's third largest foreign investor in 2013. Meanwhile, its destinations have expanded rapidly from the developing countries and resource-based countries to Europe and other developed markets. While the European market suffered from European debt, Chinese ofdi to Europe stocks and flows has increased to $\$ 40.097$ billons and $\$ 4.524$ billion in 2013 from $\$ 2.94$ billion and $\$ 1.044$ billion in 2007 . When it comes to the main destinations, it mainly flows to the UK, Luxembourg, Germany, the Netherlands, France, Norway and Sweden. And it mainly flows to manufacturing, financial services, leasing and business services, wholesale and retail trade as well as mining. Such a large scale of investment has made China become the largest partner of EU.

On this basis, Chinese-EU continued and stable trade has significantly effect on China's economic growth. But each coin has two sides. It will greatly damage our healthy development of China's economy if the trade becomes volatile. Therefore, it has practical significance to further study the geographical and industrial structure as well as its hidden reasons of Chinese ofdi to EU.

\section{Present Situation of China's OFDI to EU}

In 2013, the global economy was still in the mildest of adjustment. And global FDI grew $1.4 \%$ from a year earlier. The Chinese government makes great efforts to promote foreign investment facilitation, and perfect the strategy of "going out". In addition, China's direct investment to the European Union also greatly increased. 
Table 1: Scale of China's FDI to EU

unit: bil \$

\begin{tabular}{|l|l|l|l|l|l|l|l|}
\hline & 2007 & 2008 & 2009 & 2010 & 2011 & 2012 & 2013 \\
\hline stock & 29.42 & 31.74 & 62.78 & 125.10 & 202.91 & 315.38 & 400.97 \\
\hline flow & 10.44 & 4.67 & 29.66 & 59.63 & 75.61 & 61.20 & 45.24 \\
\hline
\end{tabular}

Notes: 1, Statistical resource:<2013 Statistical Bulletin of China's Outward Foreign Direct Investment> 2 ,the annual aggregate data does not include investment in Croatia before 2012

From table1, we can see that the size of the China's fdi to EU expanded rapidly in recent years. Although its flow decreased in 2013 but the stock had more than 40 billion dollars at the end of 2013. And since then, as the events of Xi Jinping' visit to Britain in 2015, the cooperation between China and Britain even EU will be mounted on a new platform. And it will promote the China's direct investment to EU.

\section{Analysis on Structure of China' OFDI to EU}

\section{Analysis on Geographical Structure}

Stock. From geographical structure of China's direct investment to EU, we can draw some conclusions through analyzing every region's stock in 2013.

Table 2: stock's geographical structure of China' OFDI to EU in 2013 unit: bil\$

\begin{tabular}{|l|l|l|l|l|l|l|l|}
\hline & The UK & Lu xe mbourg & France & German & Sweden & Holland & Others \\
\hline stock & 117.98 & 104.24 & 44.48 & 39.80 & 27.38 & 21.93 & 45.16 \\
\hline Per $(\%)$ & 29 & 26 & 11 & 10 & 7 & 6 & 11 \\
\hline
\end{tabular}

Notes: 1, Statistical resource:<2013 Statistical Bulletin of China's Outward Foreign Direct Investment> 2,the annual aggregate data does not include investment in Croatia before 2012

In order to see the percentage, we convert the table into pie chart below.

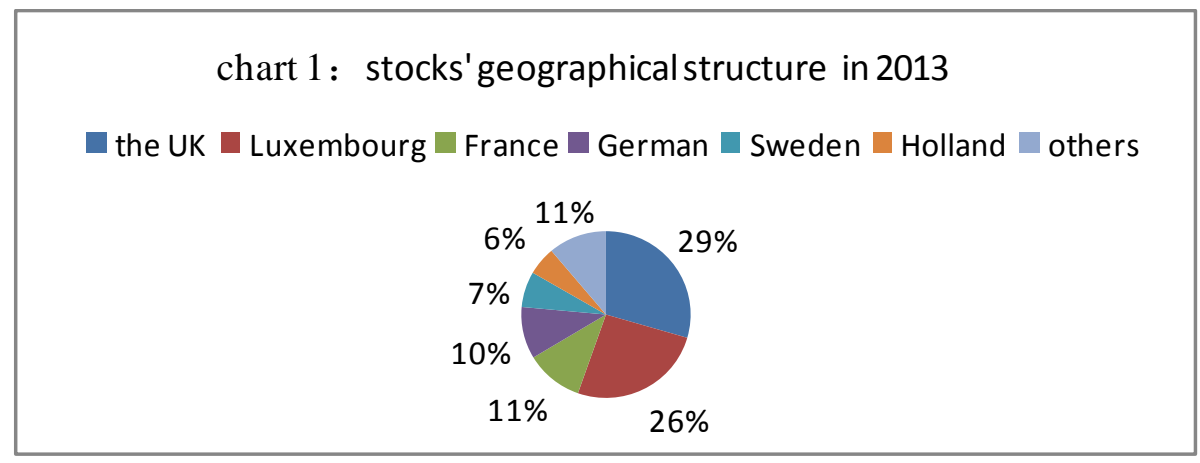

From table 2 and chart1, we can see clearly that the UK ranked first, Luxembourg ranked second. And the third country was France while Germany was fourth with $1 \%$ of the gap. In addition, Sweden was fifth and the sixth country was Holland in 2013.

Flows. In 2013, among China's ofdi to EU's flows, the UK's was $\$ 1.42$ billion, consisted $31.4 \%$ of the total flow, ranked first. While Luxembourg's was $\$ 1.275$ billion, accounted for $28.2 \%$ in the second place. In addition, Germany was $\$ 911$ million, accounted for $20.1 \%$ in the third place.

Table 3: flows geographical structure of China's ofdi to EU in 2013 unit:bil \$

\begin{tabular}{|l|l|l|l|l|l|l|l|}
\hline & The UK & Lu xe mbourg & German & France & Holland & Sweden & Others \\
\hline flow & 14.2 & 12.75 & 9.11 & 2.60 & 2.38 & 1.71 & 2.49 \\
\hline per & 31 & 28 & 20 & 6 & 5 & 4 & 6 \\
\hline
\end{tabular}

Notes: 1, Statistical resource:<2013 Statistical Bulletin of China's Outward Foreign Direct Investment $>$ 
Change it into pie chart in order to see the percentage clearly.

\begin{tabular}{|c|}
\hline chart 2: flows' geographical structure of China's ofdito EU in \\
2013 \\
the UK $\square$ Luxembourg German France $\square$ Holland $\square$ Sweden $\square$ others \\
$5 \% 4 \% 6 \%$ \\
$20 \%$ \\
$28 \%$
\end{tabular}

By table 3 and chart2, in 2013, among China' ofdi to EU's direct investment flows, the UK's was $\$ 1.42$ billion, $31.4 \%$ of the total flow, ranked first. While Luxembourg's was $\$ 1.275$ billion, accounted for $28.2 \%$ in the second place. In addition, Germany was $\$ 911$ million, accounted for $20.1 \%$ in the third place.

Summary. Above all, China's direct investment in to EU had focused on the UK, Germany, France, Luxembourg, the Netherlands and Sweden. Although annual investment flows existed certain volatility, the overall showed a rising trend and relatively fast growth.

\section{Analysis on Industrial Structure}

Stocks. From the angle of industrial distribution, it spread a wide range. But it mainly invested in manufacturing, finance, leasing and business services, wholesale and retail trade as well as mining.

Table 4: stocks' industrial distribution of China' ofdi to EU in $2013 \quad$ unit:bil \$

\begin{tabular}{|l|l|l|l|l|l|}
\hline & Manufacturing & finance & $\begin{array}{l}\text { leasing and business } \\
\text { services }\end{array}$ & $\begin{array}{l}\text { wholesale and } \\
\text { retail trade }\end{array}$ & mining \\
\hline stock & 103.28 & 86.31 & 80.27 & 41.65 & 40.74 \\
\hline per & 26 & 22 & 20 & 10 & 10 \\
\hline
\end{tabular}

Notes: 1, Statistical resource:<2013 Statistical Bulletin of China's Outward Foreign Direct Investment>

Change it into pie chart in order to see the percentage clearly.

\begin{tabular}{|l|l|}
\hline chart 3:stocks' industrial distribution of China's ofdito EU in 2013 \\
Manufacturing \\
leasing and business services \\
mining
\end{tabular}

By the table4 and chart3, it can be seen clearly that the industrial distribution of China's ofdi to EU'S the top industry was manufacturing at the end of 2013 from the angle of the stock.

Flows. From the viewpoint of traffic, manufacturing industry is topping others of China's ofdi to EU in 2013. And followed by the finance as well as leasing and business services. 
Table 5: flows' industrial distribution of China' ofdi to EU in 2013

unit:bil \$

\begin{tabular}{|l|l|l|l|l|c|}
\hline & Manufacturing & finance & leasing and business services & wholesale\& retail trade & mining \\
\hline flow & 18.05 & 14.47 & 6.76 & 3.12 & 1.91 \\
\hline per & 40 & 32 & 15 & 7 & 4 \\
\hline
\end{tabular}

Notes: 1, Statistical resource:<2013 Statistical Bulletin of China's Outward Foreign Direct Investment $>$

Change it into pie chart in order to see the percentage clearly.

chart 4:flows' industrial distribution of China' ofdito EU in 2013
Manufacturing
leasing and business services $\quad$ wholesale and retail trade
mining
m others

From table5 and chart 4 we can be seen clearly that manufacturing, finance and leasing and business services were in the first three in 2013.

Summary. Above all, we can conclude that China's ofdi to EU covered all kinds of industries. But it mainly invested in modern manufacturing and service which China didn't have advantage. In addition, it showed a rising trend.

\section{Investment Dynamics Analysis on China's ofdi to EU}

In the global investment, the theme of the investment markets are developed countries. The international investment dynamics of foreign direct investment can be divided into the following four categories: looking for resources, looking for market, looking for efficiency and looking for strategic resources. Companies always use their comparative advantages in the process of investment to reduce costs as well as increase profits. But from the perspective of China's ofdi to EU, although the regional industry and relatively concentrated distribution, but almost cover most of the industry, including the relative disadvantage of industries in China. What's more, China, as a developed country, broadly invests in the UK, Germany, France and other developed countries. And the rapid growth of the investment was more than we expected. So, it is hard to attribute China's direct investment motivation to the above four categories. We need a more convincing theory to explain China's direct investment motivation for the European Union.

We might use the theory of "extended value chain". It is more accord with China's development model for the EU's direct investment. As the largest developing country, China participates in international trade and international production networks mainly through processing and manufacturing. But at the same time, China does not have the core advantage for its manufacturing industry generally in international production chain of low-end. Therefore, China must improve the core competitiveness of manufacturing. China's manufacturing ind ustry can participate in a rapidly speed with high added value at the core of the production chain and sales network by developed countries and advanced industrial investment to EU. And we can enhance our own research and development ability by using of the high-tech talent in EU. Although the 
EU is under the background of the Europe's debt crisis, but it also provides us a lot of opportunities to enter the core EU market. As a result, we can improve our international competitive advantage of modern service ind ustry and manufacturing.

\section{Policy Suggestions for China}

Although China's direct investment to the European Union will bring a series of benefits to both countries and achieve a win-win situation. But at the same time, China will face some challenges. Such as: Chinese company management ability is insufficient and not familiar with and adapt to not for European laws and so on. In addition, the main bodies of China's foreign investment enterprises are state-owned enterprises. But in 2012, the European Union and the United States was published in the European Union and the United States on international investment joint statement proposed principles emphasized in the competition neutrality. Therefore the European Union how to define the state-owned enterprises for China is a huge challenge.

Therefore, China needs to put forward countermeasures in advance.

\section{For Governme nt}

From the angle of government, first of all, the government must continue to adhere to the "going out" strategy. And at the same time of actively establish good relations of cooperation with central Europe, we should continue to let go of the restrictions on investment and provide certain preferential investment enterprises to encourage enterprises to go out. Such as financial subsidies. Second, in the face of central Europe divisions, the government should continue to adapt the economic development of our country under the foundation of the reform of state-owned enterprises to make China's enterprises confirm to the international environment. For example, we can take state-owned company and battalion enterprise unregular investment in order to eliminate the worries about investment subject in China. In addition, Chinese can use the exchange of international talents to improve its image and recognition in the EU.

\section{For Enterprises}

The real subjects are the enterprise investment. For the enterprise, first of all, they should improve their management ability and familiar with the laws and regulations of the European market as well as cultural background in order to make them localization. Second, they should build up the idea of reform and innovation to improve their international competitiveness. In addition, they can strengthen the propaganda, improve their recognition in the European Union. Finally, increasing the concept of corporate responsibility is to set up the good enterprise image in the EU.

\section{References}

[1] S.Hymer, "The International Operations of Firms", MIT Ph.D. Thesis (1960),

[2] B.Blonigen, "A Review of Empirical Literature on FDI Determinants", NBER Working Paper 11299, (2005),

[3] C.Wang, "What Drives Outward FDI of Chinese Firms? Testing the Explanatory Power of There Theoretical Frameworks", International Business Review, Vol.21, No.3, (2012) 425-438, 
[4] Dunning.J.H, "Trade, Location of Economic Activities, And the MINE:A Resraech for An Ecletric Approach", UK. University of Reading,(1976),

[5] Dunning.J.H, "Location And the Multinational Enterprise: A Neglected Factor?" Journal of International business studies, 29(1), (1998) 45-66,

[6] Ming-Xia Zhu, "influence analysis of Chinese exports to Europe-based on the data since 1997 “, master's thesis, (2014), in Chinese,

[7] Ke Zhao, International Trade, the sixth period, (2014) 52-56, in Chinese,

[8] Jian-cong Chang, The Asia-pacific Economy, the first phase, (2015)105-110, in Chinese,

[9] Zhi-zhong Yao, Zhong-min Li, International Economic Review, the second phase, (2011)127-131, in Chinese,

[10] Xing Meng, You-de Dong, The Exploration of International Economy And Trade, volume 31, the first phase,(2015), in Chinese. 